\title{
Do Everything for the Glory of God
}

\author{
W. Scott Cleveland ${ }^{1,2}$ (D) \\ 1 Program of Philosophy, University of Mary, Bismarck, ND 58504, USA; wscleveland@umary.edu \\ 2 Program of Catholic Studies, University of Mary, Bismarck, ND 58504, USA
}

\section{check for}

updates

Citation: Cleveland, W. Scott. 2021 Do Everything for the Glory of God. Religions 12: 754. https://doi.org/ 10.3390/rel12090754

Academic Editors: J. Caleb Clanton and Kraig Martin

Received: 6 July 2021

Accepted: 3 September 2021

Published: 13 September 2021

Publisher's Note: MDPI stays neutral with regard to jurisdictional claims in published maps and institutional affiliations.

Copyright: (C) 2021 by the author. Licensee MDPI, Basel, Switzerland. This article is an open access article distributed under the terms and conditions of the Creative Commons Attribution (CC BY) license (https:// creativecommons.org/licenses/by/ $4.0 /)$.

\begin{abstract}
St. Paul writes, "whatever you do, do everything for the glory of God (1 Corinthians 10: 31 NABRE)." This essay employs the work of St. Thomas Aquinas and the recent philosophical work of Daniel Johnson (2020) on this command to investigate a series of questions that the command raises. What is glory? How does one properly act for glory and for the glory of another? How is it possible to do everything for the glory of God? I begin with Aquinas' account of glory and the pursuit of glory for God's glory and Aquinas's answers to some of the above questions that can be drawn from his discussion in De Malo. I defend Aquinas against criticisms from Daniel Johnson and present his own interpretation of the command. I advance the discussion through adding two additional interpretations that do not rely on a controversial assumption Johnson makes. Next, I address the puzzle of how we can intend everything for the glory of God using Aquinas's three-fold account of intention. Finally, I discuss the relation between charity and the desire for God's glory and how regular, actual intentions of one's actions for the glory of God increases charity.
\end{abstract}

Keywords: glory; goodness; God; action; Thomas Aquinas; charity

\section{Introduction}

St. Paul writes, "whatever you do, do everything for the glory of God (1 Corinthians 10:31 NABRE)." What is glory? How does one properly act for glory and for the glory of another? How is it possible to do everything for the glory of God? How might a person merely fulfill the command versus fulfilling it well? How might the intending of one's actions for the glory of God increase one's love for God? This essay employs the work of St. Thomas Aquinas and the recent philosophical work of Daniel Johnson on this command in order to investigate questions that the command raises.

I first outline Aquinas' account of glory and the pursuit of glory for God's glory and Aquinas's answers to some of the above questions that can be drawn from his discussion in De Malo. I then engage Daniel Johnson's interpretation of the 1 Corinthians 10:31 command, responding to several of his criticisms of Aquinas' account, and advance the discussion through adding two additional interpretations that have an advantage over Johnson's because they do not depend on a controversial metaphysical assumption Johnson makes. Next, I use Aquinas' three-fold account of intention to address how we can intend everything for the glory of God. Finally, I discuss the relation between charity and the desire for God's glory and how regular, actual intentions of one's actions for the glory of God increases charity.

\section{What Is Glory? How Ought One to Desire Glory?}

In his De Malo, Thomas Aquinas, citing St. Augustine and others, claims that glory is the manifestation of goodness to oneself, to another, to few, or to many (Aquinas 2003, p. 342). The goodness that is manifested might be material goodness (e.g., physical beauty) or spiritual goodness (e.g., wisdom) or mixed forms. Glory is increased through manifestation to many. The fitting response to the manifestation of goodness is praise. It might be thought that Aquinas holds that praise is necessary for glory. For he cites Ambrose (though the quote is likely Augustine ${ }^{1}$ ) who says that glory is "clear recognition 
accompanied by praise." However, it is not likely that Aquinas quoted Ambrose/ Augustine to support that praise is necessary for glory for the context of the quotation is to substantiate Aquinas's claim that glory is the manifestation of goodness rather than something else such as wickedness (which he calls ignominy). Here is the passage.

[G]lory signifies a clarity ... and clarity implies some evidence that makes something apparent and manifest in its splendor, and so glory implies a manifestation of someone's goodness. And if someone's wickedness be manifested, we then call it ignominy rather than glory. And Ambrose on that account says that glory is "clear recognition accompanied by praise. (Aquinas 2003, p. 342)

I interpret Aquinas to write "on that account" to make reference to the prior sentence's claim that it is goodness that is manifest. To further support this, in Aquinas' Commentary on the Letter of St. Paul to the Hebrews, he cites Ambrose again with a gloss, saying "according to Ambrose, glory is fame accompanied by praise, i.e., public knowledge of someone's goodness (Aquinas 2012, p. 14)." ${ }^{2}$ Note he does not include praise in the gloss but focuses on knowledge of goodness. It is best to say that the manifestation (or clear recognition) of goodness is fittingly accompanied by praise for a fitting or natural consequence of recognizing goodness is admiration and pleasure, which ought to lead to praise. I use 'natural' and 'fittingly' because praise need not be given by everyone who recognizes goodness, for some may, for example, fail to appreciate or be pained by the goodness and so withhold praise.

While I'm arguing that praise is not necessary for the essence of glory for Aquinas, Aquinas thinks it does accompany glory in the most excellent sense, which is God's glory in Himself. Aquinas discusses God's glory in his Commentary on Hebrews saying,

Therefore, knowledge of God's goodness is called glory in a most excellent sense, i.e., clear knowledge of the divine goodness accompanied by praise. Such knowledge is possessed by men up to a certain point ... but perfectly by God alone ... Therefore, only God's knowledge of himself is glory in the full sense, because he has perfect and clearest knowledge himself.

That is why the Apostle calls the Son the splendor of glory, i.e., of the clear divine knowledge. (Aquinas 2012, p. 15)

Aquinas's point is that glory in the full sense will involve God's perfect knowledge of his own goodness. God's own goodness is perfectly manifest only to God. In the case of God such knowledge is necessarily accompanied by joy (which in this case is similar to self-praise). Still, it is the clear knowledge of goodness itself that is the essence of glory.

Returning to De Malo, Aquinas also calls the good in question an excellence and focuses on this excellence's recognition through words, deeds, and display (Aquinas 2003, pp. 343, 349). So, the notion of glory involves goodness/excellence, its manifestation, the means of its manifestation, and the result of its manifestation (fittingly admiration and praise). However, the essence of the Aquinas' definition of glory is the manifestation of goodness to self or others. Neither a particular means of the manifestation (e.g., words, deeds, or display) nor the result of the manifestation is essential to the definition (even if the admiration and pleasure are a desirable result and will result in God's knowledge of Himself).

I now briefly explain the context of Aquinas's discussion in De Malo, which concerns the vice of vainglory. ${ }^{3}$ In this text, Aquinas's primary purpose is to outline the proper and improper reasons for a human person to desire and pursue his own glory. One desires one's own glory when one desires that one's own goodness be manifest (made clear) to self or others. For Aquinas, the desire for glory is proper when it is a means rather than an end in itself. ${ }^{4}$ It is to be a means to one's own true good (i.e., one's objective flourishing), the good of one's neighbor, or when it contributes to God's glory (which will be the focus here). 
The desire for glory is vain when the person seeks glory (1) for something that is false, (2) for something fleeting, and (3) when sought as an end or for its own sake as what will constitute one's objective flourishing. For example, a person may desire glory for his or her pleasing appearance from another. The glorying in this case is the manifestation of the goodness of one's appearance that naturally leads to admiration and pleasure that results from seeing the goodness. This example is not an instance of vainglory if the glory is desired for the sake of some good purpose. For example, if a person desires glory for her appearance because she knows she will be pleasing to one she loves. The person would desire glory vainly if it was desired merely for its own sake.

One may wonder whether God desires His glory as an end in itself or only as a means to another end. If it is an end, why is God not subject to vainglory? If it is a means, what is it a means to? While Aquinas' does not directly address these questions in his discussion of vainglory in De Malo, I'll briefly state a line of thought that could be developed to answer these questions. There are two senses in which God desires glory. The first is in the sense that He desires His goodness to be manifest to others. The second is in the sense that He desires His goodness to be manifest to Himself. Proper ends are perfective of the one properly pursuing them. If God were to pursue glory from creatures as an end, then divine perfection and happiness would depend on human glory. However, that is absurd. God does not depend on creatures for his perfection or happiness. Therefore, God does not pursue glory from creatures as an end. I suggest in Section 6 that God pursues glory from creatures as a means to the perfection of those creatures. The perfect happiness of rational creatures consists in their knowledge of God and not in their knowledge of themselves. Regarding the manifestation of God's goodness to Himself, it seems infelicitous to say that God pursues His own glory. Rather, His goodness is necessarily manifest to Himself. I think it is correct to say God's happiness consists in God's knowledge of Himself. In this sense, we might say analogously that God desires His own glory as an end and His desire is not vain. ${ }^{5}$

\section{How Does One Desire Glory for God's Glory?}

With the context for Aquinas's account of glory explained, I will now focus on his brief discussion of the pursuit of one's own glory for the sake of the glory of God, which is most germane to this essay. First, how does one desire own's own glory for the glory of another? To act for one's own glory is to act so that one's own goodness is purposefully made clear. To act for the glory of another is to act so that the other's goodness is purposefully made clear. The other's goodness can be made clear through words when one tells of the others' goodness. For example, a husband can glorify his wife by praising her prudence to another. It can also be made clear by one's own goodness when one's goodness bears a relationship to the other's goodness. For example, a daughter's good behavior can glorify her mother through revealing the goodness of her mother's instruction.

Aquinas's account of desiring one's own glory for the sake of God's glory indicates one way to understand the relationship between one's own glory and another's. Aquinas writes, "We can indeed ordain such a desire [for our own glory] for the glory of God, since manifesting one's own goodness glorifies God, to whom as first cause that goodness chiefly belongs (343)." In other words, one's own goodness is chiefly attributable to God as the first cause of goodness and secondarily to oneself. I will discuss this attributability more when engaging Johnson's discussion below. For now, I will make two points.

First, according to Aquinas, a good human desire or action is one that is in accord with God's purpose as known through human nature by reason or by divine revelation. Such desires or actions reveal human goodness and so God's goodness, which is the first cause of that goodness. Second, to do something for God's glory does not simply require manifesting one's goodness through a good action, etc., but ordaining that manifestation for God's glory. This means that the intention for manifesting one's goodness must be for the manifestation of God's goodness (in addition to any other proper motivations that may be at play such as love for one's neighbor). Hence, this ordination adds an ordering of the 
action. For example, if a person were to do a virtuous action in a virtuous way because it was virtuous, such a person's goodness would bring glory to God but he would not be ordaining that goodness to God's glory without some intention to do so. To ordain that virtuous action for God's glory requires not only desiring to do it for its own sake but also for the sake of the glory of God. I now will introduce a contemporary interpretation of the 1 Corinthians 10:31 command that will set the stage for addressing a series of puzzles that arise.

\section{Daniel Johnson's Kierkegaardian Account}

\subsection{Context}

Daniel Johnson (2020) presents a plausible interpretation of the 1 Corinthians 10:31 command according to which we are "commanded to intentionally make every one of our actions such that it simultaneously counts as a divine action: in other words, to act intentionally in all things such that it is God who acts through us (Johnson 2020, p. 1)."

The context for Johnson's interpretation is his Kierkegaardian solution to the Problem of Total Devotion as posed by Robert Adams (1993). I will briefly explain this context because it lays the foundation for his discussion of the 1 Corinthians 10:31 command. Johnson presents the Problem of Total Devotion as a dilemma. He writes,

two claims are asserted which seem on the face of it at least to be in tension: that our devotion to God ought in some important sense be total, and that we ought to appreciate and love the created world (which is not God), especially other human beings. The more we insist that our devotion to God be total, the more we seem to exclude or water down love of created things and other people; call this the Denial of Creaturely Love horn of the dilemma. On the other hand, the more we insist that we love other people (and other created things) for themselves, the more we seem to demote God to merely first among a constellation of independent goals, and replace total with merely partial devotion to God; call this the Idolatry horn of the dilemma. Either we fail to love creatures as we should, or we fail to love God as we should. (Johnson 2020, p. 2)

Johnson illustrates the dilemma through discussion of two possible resolutions. The first resolution is to love everything for the sake of God and nothing for its own sake, which Johnson rejects for it fails to involve proper love of creatures. The second resolution is "putting God first", in which God is loved more than anything else. Johnson believes this resolution does not necessarily exclude idolatry for love for God doesn't seem total. His goal is to provide an explanation of the relationship between the love of God and creatures that avoids both horns of the dilemma.

His solution is Kierkegaardian for it involves his interpretation of Kierkegaard's use of the notion of loving God as the 'middle term' such that "you love your neighbor through your love for God" (Kierkegaard 1962, p. 70 as cited in Johnson 2020, p. 4). Johnson uses a Thomistic account of love according to which love involves desire for the good of the beloved, desire for union with the beloved, and appreciation for the beloved (Pruss 2011). He explains that,

To love another with God as the 'middle term' could be to appreciate them under descriptions relating to God (or, equivalently, to appreciate aspects of them related to God) and on the basis of that appreciation desire their good and union with them. (Johnson 2020, p. 4)

In other words, I may love God totally when everything I love I appreciate in part because I relate it to God. For example, I love my neighbor in part under descriptions (or aspects) such as my neighbor as beloved by God, or my neighbor as made in God's image, etc. Instead of simply loving my neighbor as a fellow human being, when I love her I think to myself, "I love her as one made in God's image and beloved by God." I'm now loving her in relation to God through the descriptions I ascribe to her or aspects that I focus on when I love her. 
On this view, the love of a creature is an extension of the love of God in the following sense. Johnson writes,

love with God as the middle term is defined in terms of the sort of appreciation you have: you appreciate others under descriptions that relate them to God. Now, you can't appreciate others because they reflect or relate to God unless you already appreciate God. If you don't appreciate God-that is, find him good-then you won't appreciate someone because they reflect God-that is, you won't find that aspect of them to be good. (Johnson 2020, p. 6)

By loving all creatures with the love of God as the middle term, there is no competition between the love for a creature (even for its own sake) and the love for God.

These are the essential parts of Johnson's Kierkegaardian solution to the Problem of Total Devotion. Johnson develops the view a bit more and addresses some objections to his view, but these need not concern us here. I turn now to explain his extension of his Kierkegaardian solution to the problem of Total Devotion to an interpretation of the 1 Corinthians 10:31 command.

\subsection{Interpretation of 1 Corinthians 10:31}

Johnson's interpretation of 1 Corinthians 10:31 begins with an explication of his understanding of Aquinas's sense of glory. Johnson believes Aquinas' view is that glory includes God's excellence and the praise that results from a person appreciating God's excellence. Johnson claims that according to this view, the 1 Corinthians 10:31 command should be understood as, "in all things act so that God will be praised as a result (Johnson 2020, p. 12)." Johnson then levels some criticisms of this interpretation of the command.

Whether Johnson's interpretation of Aquinas is correct or not, the view can avoid an objection Johnson levels against it. His first objection against the view that one should "in all things act so that God will be praised as a result" is that such a view is inconsistent with a person being mocked for his good deed. In other words, the view fails because a person may do good so that God will be praised and fail to produce that praise through no fault of his own. However, the view Johnson criticizes does not imply that everyone who witnesses one's good deed will give praise. Is it not enough that someone praises God? The one who praises God could be the one who did the good deed herself or God's angels or the saints who are the great cloud of witnesses mentioned in Hebrews 12:1. We can assume that the latter perfectly virtuous audience would give praise to God for the deed. So, Johnson's objection would work only if the command were interpreted as "act in such a way that everyone who sees the goodness of the act praises God."

In a broader defense of Aquinas, one need not read the text of De Malo as implying Johnson's interpretation. Aquinas does not himself state that praise necessarily follows glory as I argued above. As discussed, he suggests it naturally or fittingly follows glory. His sense of 'glory,' as argued above, is essentially the manifestation of goodness. Returning to the objection from mockery above, it is fitting for the person being mocked for his good deed to be praised even if he is not praised. The additional response to that manifestation will depend on the free choice of the creature.

Johnson mentions another way to interpret Aquinas that tracks with the idea that the praise ought to follow even if it does not in every case of glory, which is "in all things act so that God ought to be praised or deserves to be praised (Johnson 2020, p. 12, footnote 16)." Johnson replies, "I think this collapses into the interpretation I ultimately defend, since for God to deserve to be praised for an action that I do, he must deserve credit for my action, and so my action must in some way be ascribable to him (Johnson 2020, p. 12, footnote 16)." I'll simply note that just because this interpretation may collapse into his own is not a sufficient reason to reject it as a plausible way to interpret Aquinas's view even if it's less interesting as a foil to Johnson's view. Johnson is interested in exploring other resources and introduces an aspect of glory he takes from Jonathon Edwards. Edwards holds that in addition to 'glory' referring to God's excellence and any praise given to God for it, God's glory also refers to God's deeds that manifest God's excellence. 
Johnson utilizes this sense of glory to argue that the best way to understand the commandment is as the command for us to make

our actions a constituent part of a larger excellent deed of God's. "We can act as his hands, as it were, such that our actions constitute God's excellent actions, which in turn constitute God's glory" (Johnson 2020, p. 13)

However, it is not enough for us to fulfill the command for our good actions to be constitutive of God's. We must intend our actions considering that they are constitutive of God's deeds. He elaborates "It would be a command to intend all of our good deeds under the description constitutive of the deeds of God or some related description (Johnson 2020, p. 13)."

\subsection{The Metaphysical Possibility of Johnson's Interpretation}

Given that his account requires that all human actions partially constitute divine actions, Johnson articulates two ways this could be metaphysically possible. He calls the two approaches Divine Providence and Divine Authorization.

According to Divine Providence, assuming a privation view of evil, "all of the good things that happen constitute divine actions, and none of the bad things constitute divine actions (Johnson 2020, p. 16)." The upshot is that

then the actions that are required by that command turn out to be coextensive with the actions you already have reason to do: the good ones. So the command will require the same actions that were already required; it just requires also a particular kind of additional motivation for performing those actions: don't just do them because they are good, but also because in doing them you get to be part of what God is doing. (Johnson 2020, p. 16)

According to Divine Authorization, God authorizes all and only those actions that are part of the mission God ordains for His representatives. His representatives are authorized to act on His behalf and in performing actions in accordance with the mission for which they are authorized, they act as agents of God. This implies that to do everything for God's glory limits a person to those actions that are in accordance with the divinely ordained mission. Citing Wolterstorff (1995) on deputized speech, Johnson addresses the objection that God has not provided sufficient commands to cover everything necessary to fulfilling the mission by saying,

the general missions given by God might leave quite a bit of discretion in the hands of his commissioned representatives to decide precisely how the mission is to be carried out, and nevertheless if the actions decided upon by the commissioned representatives are intended to fulfil the mission, they can still count as divine actions. (Johnson 2020, p. 17)

Johnson does not choose between Divine Providence and Divine Authorization nor does he rule out the possibility of other alternatives. On either account it is metaphysically possible to fulfill his interpretation of the 1 Corinthians 10:31 command.

\subsection{Discussion of Johnson's Interpretation}

Johnson's account is plausible. However, I want to offer two additional interpretations of the 1 Corinthians 10:31 command beyond his, which is, again, to "intend all of our good deeds under the description constitutive of the deeds of God." While I think that Johnson's interpretation has value, which I discuss in Section 6, I think these two additional interpretations have equal value and further advantages. One advantage is that they remain neutral on the claim that Johnson's interpretation requires, which is that every good deed is necessarily constitutive of God's deed. While this claim may be true, my interpretations do not rely on it, which makes these interpretations more plausible. However, I do not argue that my interpretations contradict Johnson's interpretation. So, those who affirm 
Johnson's above claims can still accept my interpretations. However, my interpretations stand even if Johnson's view is false.

The first alternative interpretation of the 1 Corinthians 10:31 command is that we are to intend our good deeds under the description attributable to the deeds of God. This more general description is a way to understand the command that may appeal to those who do not accept that every good deed is necessarily a divine deed and so who think the command could be fulfilled without intending every action as constitutive of the deeds of God. Intending actions under this description is intending them for the glory of God because the actions are intended with reference to way(s) the agent understands the good action to be attributable to God's deeds (or work or power). For example, I intend some good action as attributable to the deeds of God in sustaining my existence and providing the grace needed to perform the action. My deed does manifest God's goodness in sustaining my existence and providing grace and I recognize that through intending my action with this description.

The second alternative is more specific and is intending our good deeds under the description of a gift from God to be offered back to God. This description captures a grateful acknowledgement of the divine source-hood of goodness (on the assumption that all goodness is from God), while also remaining neutral on the claim that every action constitutes a divine action. The language of 'gift' acknowledges that what is received from God is both good and gratuitous. The language of 'offering' suggests an exchange of love prompted by gratitude and a desire to reciprocate God's love. This reciprocated good-will is the basic condition for friendship. So, acting under this description is also a reminder of God's desire for friendship with a person and signals the person's desire to promote his loving union with God. Intending actions under this description is intending them for the glory of God because the divine source of the action's goodness is acknowledged while one seeks to do the good out of love for and desire to please God, who wishes the person to relate these gifts back to Him. God's goodness is manifest through His love in giving good things and His desire that these good things be sources of greater union between God and creatures, and this is recognized through intending actions with this description.

Johnson might object that these alternatives do not adequately involve acting for God's glory because the actions are not intended as constitutive of God's deeds. He claims, "for God to deserve to be praised for an action that I do, he must deserve credit for my action, and so my action must in some way be ascribable to him (Johnson 2020, p. 12, footnote 16)" and assumes the way in which my action is ascribable to God is that it be constitutive of the deeds of God. The key assumption is this: my actions are ascribable to God such that God deserves praise because of them only if my actions are constitutive of God's deeds. Johnson starts from rather than defends this assumption. As the above alternatives make clear, I want to retain that good actions are ascribable to God such that God can receive praise because of them without requiring the stronger claim that the only way for God to receive praise is if those actions are constitutive of God's deeds. I now motivate the claim that whether my action is constitutive of God's action or not, it is possible that God can still deserve praiseworthy credit because of my action.

Consider some human analogies. A mother is praised for her daughter's good character. A coach is praised for his athlete's good performance. A teacher is praised for her student's knowledge. A master craftsman is praised for his apprentice's craftmanship. The mother, coach, teacher and master craftsman merit praise even when the deeds of their protégé are not constitutive of their own deeds. Yet the protégé's success depends on the good deeds of the superior in training them well. The goodness of the superior is manifest in the goodness of the protégé. The forming of the protégé to do well gives the superior a special kind of glory distinct from the inner glory the superior displays in performing his or her own individual excellent deeds. They were also able to pass on their own goodness to others. 
To apply back to my alternatives, the athlete may compete under the description attributable to the deeds of my coach. More colloquially, the athlete might say, "I'm doing this for coach." In this way, they want to manifest their own athletic excellence as a tribute to the good training they've received from the coach. The athlete's excellent performance does glorify the coach and the athlete intends it to. A daughter might perform some courageous action out of gratitude for the gift of the good upbringing that her mother provided and to please her mother through satisfying her mother's desire for deeper friendship with her virtuous offspring. Such an action testifies to her mother's excellence and so brings the mother glory and foster love between the daughter and mother and the daughter intends it to.

God's relation to creation is analogous to the above in some cases. The analogy holds for there is a goodness of God that is manifest by His goodness to others such that they now possess God's goodness and can make use of it as an offering back to God in gratitude. Our intention in acting for God's glory should capture this truth. This is seen most clearly in God's gift of grace to persons to elevate them to share in his divine life, which I will discuss more below. God's relation to creation is disanalogous to the above cases in that God is also the first cause of the creatures' existence, nature, causal powers, etc., and every good in a creature is attributable to God in some way, while not every good in the protégé is attributable to the superior. However, these disanalogies do not undermine my point. Returning to the analogies, hopefully the protégé wishes to acknowledge the debt to his superior by in part doing well in the future out of gratitude for the superior. So too, those who order their acts to God's glory should want in the description of their intention a grateful acknowledgement of what they have received and loving return to God.

In summary, I claim that to intend all of our good deeds under the description attributable to the deeds of God may provide a broader description of the intention open to more metaphysical options and that intending our good deeds under the description of a gift to be offered back to God is also open to more metaphysical options as well as helping us gratefully to acknowledge God as the source of our goodness through offering our goodness back to Him. Neither require the metaphysical assumption that our good deeds are constitutive of the deeds of God. Nor do they require, even if this metaphysical assumption is true, that we knowingly intend our actions under that description. These are advantages of these alternatives.

\section{How Does One Do Everything for the Glory of God?}

The puzzle I address in this section is, how can one order every action for God's glory? This puzzle is raised by other commands such as to "pray without ceasing" and to "love God with all your heart." It seems impossible for human beings to actually and consciously intend every action be performed as "for God's glory." So, is this an impossible command?

Johnson, similar to Aquinas, answers this question by making a distinction between consciously intending at the time of action and a prior intention that remains unconscious while performing the action. He exemplifies the distinction as follows,

I think it fair to say that I walk to my office in part in order to provide health insurance for my family. That was a big part of my motivation in taking the job, and a big reason I don't leave to do something else, or sleep in and skip work. But I'm not thinking of that every morning I go to do my job. (Johnson 2020, p. 14)

This distinction between a conscious present and a currently unconscious but prior intention can account for how the command to do every action for God's glory may be fulfilled without one consciously intending it during every act. For Johnson, the prior intention must not only persist but be motivating in some way. He describes the example of eating and drinking for the glory of God as follows, 
The glory of God-that is, the prospect of participating in God's activity in the world, of doing God's work - must actually enter into my motivation for eating and drinking. That is harder, and requires that a concern to act as God's agent runs pretty deep in my character. (Johnson 2020, p. 15)

Johnson does not explain what it means for the glory of God to "actually enter into my motivation for eating and drinking." Aquinas offers another distinction that helps understand this motivation.

The three-part distinction is between actual, virtual and habitual ordering to an end. ${ }^{6}$ Actual ordering is when there is a conscious intention (or motivation) in the moment of acting. Virtual and habitual ordering do not involve a conscious intention in the moment of acting. Virtual ordering is the unconscious ordering of an action to an end from a prior conscious intention. It is "the continued existence of the [past] actual intention in its effect. The actual intention is not present itself, but its influence and causation remain (Skrzypczak 1958, p. 50)." Habitual ordering is the habitual ordering of a person to an end. The habitual ordering of a person becomes a virtual ordering in action and, similar to virtual ordering, presupposes a prior conscious direction. For example, if a person has habitually ordered himself to loving his wife and children, then that habitual order remains in his actions and when doing nothing while asleep. Since it is a habitual ordering of his person, all his actions are at least incidentally ordered to loving his wife and children. In fact, all his actions are at least incidentally ordered to all his habitually ordered ends. Similar to plans, habitual ordering persists until it is removed by an opposing action (Jensen 2018, pp. 17-20). ${ }^{7}$

To apply this distinction to the issue of motivation in acting for the glory of God, I will present Aquinas's answer to a related question, what kind of motivation or intention is required for every action in order to avoid breaking the command? Aquinas writes,

This precept [do all to the glory of God] of the Apostle is affirmative, and so it does not bind for all times. Consequently everyone who does not actually refer all his actions to the glory of God, does not therefore act against this precept. In order, therefore, to avoid mortal sin each time that one fails actually to refer an action to God's glory, it is enough to refer oneself and all that one has to God habitually. (Aquinas 1920, Summa Theologiae, I-II, Q.88, 1 ad 2, emphasis added)

For Aquinas, to habitually refer oneself to God (and to acting for God's glory) suffices for fulfilling the command when one fails to actually refer an action to God's glory. In other words, failing to actually and consciously intend an action for God's glory does not break the command to do everything for the glory of God so long as a person is habitually ordered to God and acting for God's glory. For as long as one is so habitually ordered, all that one does is as at least incidentally ordered to God. However, while incidental order may suffice for not breaking the command, it alone is not the ideal. For we may still commit other sins that are not contrary to charity (i.e., venial sins) while retaining our habitual order as a person to God. Such sins cannot be virtually ordered to God for no sin can be actually or virtually intended for the sake of loving God above all things and acting for God's glory (Jensen 2018, p. 37). Hence, the ideal is to habitually order our person and virtually order all our actions to God and His glory. Aquinas explains the importance of this virtual ordering in his discussion of the injunction to pray without ceasing.

The cause of prayer is the desire of charity, from which prayer ought to arise: and this desire ought to be in us continually, either actually or virtually, for the virtue of this desire remains in whatever we do out of charity; and we ought to "do all things to the glory of God" (1 Corinthians 10:31). From this point of view prayer ought to be continual: wherefore Augustine says (ad Probam, Ep. cxxx, 9): "Faith, hope and charity are by themselves a prayer of continual longing. (Aquinas 1920, Summa Theologiae II-II, 83, 14) 
Charity includes the habitual ordering of ourselves to God such that we love God above all things. This habitual ordering of our person results in a virtual ordering of our actions unless we sin in such a way that we remove our habitual ordering. For example, if a person is habitually ordered to love God with her whole heart, then if she were to act in a way consciously contrary to that love, she would remove that habitual ordering. However, if she were to $\sin$ in a way that was neither actually nor virtually ordered to the love of God nor contrary to the love of God, then her habitual ordering to love God with her whole heart would remain. Hence, Jensen says that a habitual ordering gives character to a person while a virtual ordering gives character to an action (Jensen 2018, p. 37). If we were to actually or virtually order all our actions to the love of God and His glory, we would only do what is good. However, if we were habitually ordered to God but were to sin in such a way that we do not remove that ordering, our action would be habitually ordered to God incidentally but not actually nor virtually.

The three-fold distinction between actual, habitual and virtual ordering is helpful to clarify what is required (namely, habitual ordering) for every act to be carried out for the glory of God and why the command is not broken when one fails to refer an action consciously and actually to the glory of God. Virtual ordering explains how one gives character to an action ordered to God's glory even when one is not actually and consciously intending that end.

The passage from Aquinas above also links charity to the 1 Corinthians 10:31 command. I will discuss that link more and Johnson's claim that fulfilling the command "requires that a concern to act as God's agent runs pretty deep in my character." Charity involves the habitual ordering of ourselves to God such that we love God above all things. However, this can have a deeper or shallower root in a person's character. After all, the Christian needs to grow in charity. We should distinguish between the bare minimum requirement for fulfilling the command to do everything for the glory of God and a more mature fulfillment of the command. Aquinas claims below that the perfection of charity in this life requires intending all things virtually for the glory of God, while the perfection of charity in heaven requires intending all things actually for the glory of God. He writes,

... it must be said that to order all things actually to God is not possible in this life; just as it is not possible to be always thinking of God, for this pertains to the perfection of heaven. But that all things be ordered to God by virtue does pertain to the perfection of charity, to which all are bound. To prove this, it must be understood that just as in efficient causes the power of the primary cause remains in all the subsequent causes, so also does the intention of the principal end virtually remain in all the secondary ends. Thus, whoever actually intends some secondary end, virtually intends the primary end. For example, a physician, while actually gathering herbs, intends the end of preparing a prescription, while perhaps not thinking about health; virtually, however, he intends health as the end for which he administers the prescription. In the same way, he who orders himself to God as to an end, in all things which he does for his own sake, the intention of the final end which is God remains virtually. Thus he is able to gain merit in all things if he has charity. It is in this manner, therefore, that the Apostle wrote that everything should be ordered to the glory of God. (Aquinas 1960, Q2, 11 , ad 2, ad 3 emphasis added)

Those in heaven lack the impediments to perfect charity that we have in this life such as distracting sinful inclinations, preoccupations with temporal affairs and physical limitations and infirmities (Aquinas 1960, Q2, 10). However, we can grow in charity through acting contrary to sinful inclinations and making time and opportunity for thinking of and consciously acting for the love and glory of God. While it is impossible to achieve the perfection of charity enjoyed by those in heaven in this life, that state represents the ideal we are to strive for in accordance with our duties in this life. It is plausible that the more we actually and consciously order our actions for the love and glory of God in accordance with 
our duties in this life, the better we will fulfill the command and the deeper the concern to act as God's agent will run in our character.

\section{Desire for God's Glory and the Increase of Charity}

Lastly, I discuss the relation between charity and the desire for God's glory and how actually intending one's actions for the glory of God increases charity. What I say here applies even if Johnson's interpretation is correct and so I include his interpretation in what follows. I claim that regular actual and conscious intention of actions under descriptions such as constitutive of the deeds of God, attributable to the deeds of God or as a gift from God to be offered back to God helps the agent to consciously participate in joint-action with God and facilitates an increase in love for God and sensitivity to more effective ways of promoting His glory.

One of the greatest ways that human beings manifest God's goodness is when God gives a human being grace and elevates her to be habitually ordered to the end of supernatural life, which is perfect union with God in heaven, or to be partakers of the divine nature as is said in 2 Peter 1:4. This is supernatural goodness because the goodness exceeds the natural goodness of human beings. God grants the supernatural power to advance toward being fit for life in heaven, especially by giving the virtue of charity through which a person loves God above all things. God is present in such a person by the Holy Spirit working within the human person to bring that person to eternal, supernatural life and to enable that person to help in God's work of bringing others to enjoy the same life.

The practice of regularly actually intending one's actions under descriptions such as constitutive of the deeds of God, attributable to the deeds of God, or as a gift from God to be offered back to God reminds the person that God and human beings are joint laborers in the work of eternal life and that a person's work depends on God's work within herself. The supernatural good deeds freely chosen by those in grace are a result of their cooperating with God working in them (e.g., Philippians 2:13). God is always attending to His work in persons even when we are not paying attention. To consciously work with God involves shared attention with God and awareness of one's union with God in the work. Regular actual intentions under these descriptions increases the union of mind and will that a person enjoys with God by the person's re-establishing that joint attention. Regularly drawing one's own attention to this union ought to increase one's love for God, especially through appreciating God's goodness in acting for one's good and enabling one to act in union with God in furthering one's good and God's glory.

Finally, we will seek ever greater ways to reveal God's glory when we see that glory's connection to God's love for us. God wants glory and commands us to do all for his glory out of love. God created to manifest his goodness. Why? To see the glory of God is the greatest blessing for persons for it elicits, increases and satisfies love for God. Aquinas writes, "To know God's goodness is the ultimate end of a rational creature, since happiness consists of this. And so the glory of God is not to be related to anything else. Rather it is proper to God himself that rational creatures seek his glory for its very self. But the knowledge of no creature's goodness makes a rational creature happy. And so we seek no glory of a creature for its own sake but for the sake of something else (Aquinas 2003, p. 344)." God created to manifest his goodness to creatures because the knowledge of God's goodness is the source of happiness for all persons. God's love for us is shown by willing for us the highest good—our happiness through knowing God's goodness. Reciprocating God's love is the only proper response and that involves manifesting God's goodness. This connects the love for God and desire for God's glory. By ordering everything to the glory of God, we join in God's loving purpose for creation—for its fulfillment through the knowledge and love of God. 


\section{Conclusions}

The purpose of this essay was to better understand the command to do everything for the glory of God in 1 Corinthians 10:31. I outlined Aquinas's account of glory and addressed questions concerning what glory is and how ought one to desire glory for God's glory. I responded to several criticisms of Aquinas's account by Johnson and presented Johnson's interpretation of the 1 Corinthians 10:31 command: that one intends one's action as constitutive of the deeds of God. I provided two interpretations that go beyond Johnson's that do not depend on a controversial metaphysical assumption he makes and motivated their plausibility. The first was to act with the intention description as attributable to the deeds of God. The second was to act with the intention description as gift from God to be offered back to God. I used Aquinas's threefold account of intention to address the deep puzzle of how we can do everything for the sake of God's glory. We fulfill the command to act for God's glory with perfect charity in this life when we intend all our actions, actually or virtually, to the end of manifesting God's goodness. Finally, I discussed how one might grow in love through regularly and actually intending actions under the above descriptions for the manifestation of God's goodness. ${ }^{8}$

Funding: This research received no external funding.

Conflicts of Interest: The author declares no conflict of interest.

\section{Notes}

See Brian Davies's footnote 6 in Aquinas (2003, p. 342).

See section 26 of Lecture 2, Chapter 1 of (Aquinas 2012) for the context.

See Rebecca DeYoung's (2014) Vainglory for deeper discussion of vainglory.

In Summa Theologia I-II.2.3, Aquinas argues that man's happiness cannot consist in his glory in the sense that human flourishing depends on another human's knowledge of one's goodness. However, Aquinas does say that human happiness depends on God's knowledge as its cause. Hence, in this special case, human happiness depends on the glory he has with God for God's knowledg is the cause of his good.

5 I thank an anonymous reviewer for raising these questions.

6 The following discussion is informed by the fuller treatments of Jensen (2018), Osborne (2008), and Skrzypczak (1958).

7 For Jensen's own explanation, see the following quote.

For an actual order to the end, a person consciously directs his action to some end, as when Anna consciously directs her act of driving to the end of getting milk. For the virtual order, someone who has previously directed his action to an end, need not always be thinking upon this end in order to maintain the direction to the end. While driving, Anna need not be thinking about the milk; her action will retain, virtually, the order to the end of getting milk ... Habitual order is best approached through habitual love ... To love someone is to seek his good ... A mother loves her child sometimes in act, sometime virtually, and sometimes habitually. She loves him in act when she is driving him to school, consciously directing the action to his good. She loves him virtually, when she is driving him to school but is not now thinking upon him, although she has previously directed the act of driving to his good. She loves him habitually throughout the day and even at night while she sleeps. This love remains with her all the time. A mother loves her son while she sleeps, while she reads a novel, and while she exercises ... She still loves her son while performing these actions, even if she has not previously directed these actions to his good ... [Habitual order] is more of an order of the person than of her actions (Jensen 2018, pp. 18-20).

8 I wish to thank Lindsay Cleveland and Jeremy Skyrzpek for their helpful comments on this paper and David Echelbarger and Donald Bungum for helpful discussion of Aquinas' three-fold notion of intention, which was applicable to this essay.

\section{References}

Adams, Robert M. 1993. The Problem of Total Devotion. In Friendship: A Philosophical Reader. Edited by Neera Kapur Badhwar. New York: Cornell University Press, pp. 108-32.

Aquinas, Thomas. 1920. Summa Theologiae, Second and Revised Edition. Translated by Fathers of the English Dominican Province. New York: Benziger Brothers.

Aquinas, Thomas. 1960. On Charity. Translated by Lottie H. Kenzierski. Milwaukee: Marquette University Press, Available online: https://isidore.co/aquinas/english/QDdeVirtutibus2.htm\#11 (accessed on 3 September 2021).

Aquinas, Thomas. 2003. On Evil. Edited by Brian Davies. Translated by Richard Regan. Oxford: Oxford University Press. 
Aquinas, Thomas. 2012. Commentary on the Letter of Saint Paul to the Hewbrews. Edited by John Mortensen and Enrique Alarcón. Translated by Fabian Richard Larcher. Lander: The Aquinas Institute for the Study of Sacred Doctrine.

DeYoung, Rebecca Konyndyk. 2014. Vainglory: The Forgotten Vice. Grand Rapids: Wm. B. Eerdmans Publishingm.

Jensen, Steven J. 2018. Sin: A Thomistic Psychology. Washington, DC: CUA Press.

Johnson, Daniel M. 2020. Doing All Things for God's Glory, Acting so That It Is God Who Acts: Kierkegaard, Edwards, and the Problem of Total Devotion. Religious Studies, 1-20. [CrossRef]

Kierkegaard, Søren. 1962. Works of Love. Translated and Edited by H. V. Hong, and E. H. Hong. New York: Harper \& Row.

Osborne, Thomas. 2008. The Threefold Referral of Acts to the Ultimate End in Thomas Aquinas and His Commentators. Angelicum 85: 715-36.

Pruss, Alexander R. 2011. From Love to Union as One Body. In Fertility and Gender: Issues in Reproductive and Sexual Ethics. Edited by Helen Watt. Oxford: The Anscombe Bioethics Centre, pp. 17-27.

Skrzypczak, Edmund Robert. 1958. Actual, Virtual, and Habitual Intention in St. Thomas Aquinas. Available online: https: / / ecommons.luc.edu / cgi/viewcontent.cgi?referer=https: / / scholar.google.com.tw / \&httpsredir=1\&article=2700\&context=luc _ theses (accessed on 3 September 2021).

Wolterstorff, Nicholas. 1995. Divine Discourse: Philosophical Reflections on the Claim That God Speaks. Cambridge: Cambridge University Press. 